\title{
Ecological Regime Shifts in Lake Kälksjön, Sweden, in Response to Abrupt Climate Change Around the 8.2 ka Cooling Event
}

\author{
Linda Randsalu-Wendrup, ${ }^{1 *}$ Daniel J. Conley, ${ }^{1}$ Jacob Carstensen, ${ }^{2}$ \\ Ian Snowball, ${ }^{1}$ Catherine Jessen, ${ }^{3}$ and Sherilyn C. Fritz ${ }^{4}$
}

\begin{abstract}
${ }^{1}$ Department of Geology, Quaternary Sciences, Lund University, Sölvegatan 12, 22362 Lund, Sweden; ${ }^{2}$ Department of Bioscience, Aarhus University, P.O. Box 358, 4000 Roskilde, Denmark; ${ }^{3}$ Research \& Exhibitions Danish Prehistory and Environmental Archaeology, The National Museum of Denmark, Ny Vestergade 11, Forhuset, 1471 Copenhagen K, Denmark; ${ }^{4}$ Department of Earth and Atmospheric Sciences, University of Nebraska, Lincoln, Nebraska 68588, USA
\end{abstract}

\begin{abstract}
A detailed diatom record from Lake Kälksjön, westcentral Sweden, reveals two periods of abrupt ecological change correlative with the $8.2 \mathrm{ka}$ cooling event. Using a combination of abrupt step changes and piece-wise linear regressions, the diatom data were analyzed for change points over time, and two sudden and large events that are described as regime shifts were detected. During the first event at c. 8040 cal. y BP, a doubling in diatom biomass took place over $5-10$ years. This increase in primary productivity can be connected to an erosion event in the catchment that resulted in an abrupt increase in nutrient supply to the lake. The second event was characterized by a substantial shift within the planktonic diatom community from taxa indicative of colder conditions to those indicating warm over 5-10 years at c. 7850 cal. y BP. This event was superimposed on a successive change from periphytic to planktonic
\end{abstract}

diatom dominance over a 250-year period and a gradual diversification of the periphytic community that spanned c. 150 years. Rapid climate warming following the $8.2 \mathrm{ka}$ event likely caused these changes and both regime shifts are examples of externally driven abrupt ecological change. This study demonstrates that it is possible to detect, quantify and test for regime shifts in paleoecological data, and it highlights the need for high sampling resolution and precise chronological control. High-resolution paleoecological reconstructions of ecological regime shifts in response to climate change can provide useful analogues of future changes in ecosystem structure and functioning.

Key words: thresholds; regime shifts;

lake sediment; varves; diatoms; Sweden; climate; Paleolimnology; 8.2 ka event.
Received 4 April 2012; accepted 25 July 2012; published online 11 September 2012

Author Contributions: LRW, DJC, JC and IS designed the study; LRW, IS and CJ performed research; LRW, JC, SCF and DJC analysed data; JC developed the numerical methods; LRW wrote the article with contribution from all co-authors.

*Corresponding author; e-mail: Linda.randsalu_wendrup@geol.lu.se

\section{INTRODUCTION}

Abrupt climate change and associated or independent abrupt ecological change has been observed in various ecosystems, including marine environments (for example, Beaugrand 2004; Collie and others 2004; Spencer and others 2011), Arctic lakes 
(Smol and others 2005; Rühland and others 2008), brackish lagoons (Jeppesen and others 2007), terrestrial ecosystems (Dearing 2008), coastal areas (Conley and others 2009; Duarte and others 2009) and shallow lakes (for example, Scheffer and van Nes 2007; Scheffer and Jeppesen 2007; Zimmer and others 2009). Abrupt changes, whether climatic or ecological, are often described as "regime shifts": sudden events that lead to rapid climate or ecosystem reconfiguration between alternative stable states (Lees and others 2006; Andersen and others 2009). When detected, past regime shifts offer rich opportunities to study the patterns and drivers of abrupt ecological change and to understand ecosystem responses to climate changes that may take place in the near future. Abrupt ecological changes have been a common phenomenon during the late Quaternary and have often been driven by abrupt climate changes, also frequent and widespread during this time (Williams and others 2011).

One manifestation of abrupt climate change is the " 8.2 ka cooling event" which is assumed to be the highest magnitude climate change of the Holocene in the northern mid to high latitudes (Daley and others 2011). The event is believed to have been caused by the injection of glacial melt water from ice-dammed Lake Agassiz-Ojibway into the Labrador Sea (for example, Clarke and others 2004; LeGrande and others 2006; Wiersma and Renssen 2006; Daley and others 2011), slowing down the ocean thermohaline circulation (THC) and its associated heat transport (for example, Alley and others 1997; Barber and others 1999; Wiersma and Renssen 2006) and leading to a pronounced transient cooling in the North Atlantic region (Wiersma and Renssen 2006; Daley and others 2011). Analysis of Greenland ice-core records indicates that an abrupt cooling event began around $8175 \pm 30 \mathrm{cal}$. y BP and lasted for c. 150 years, with maximum cooling of c. $3^{\circ}$ lasting c. 70 years (Kobashi and others 2007). The event and its impact, however, remain to be understood in detail (Snowball and others 2010). Rohling and Pälike (2005) argue that the short but intense 8.2 ka event was superimposed on a more general cooling in the Northern Hemisphere, which began at c. 8600 cal. y BP and lasted for several centuries, and it has been suggested that the climate in Fennoscandia (Norway, Sweden, Finland and parts of north-western Russia) was characterized by two or three colder episodes during a c. 400-year period centred on $8000 \mathrm{cal}$. y BP, rather than a single event (Ojala and others 2008; Zillen and Snowball 2009). A cooling episode around $8200 \mathrm{cal}$. y BP has been described in several proxy records in the
Northern Hemisphere (for example, Alley and others 1997; Tinner and Lotter 2001; Veski and others 2004; Hammarlund and others 2005; Ojala and others 2008; Panizzo and others 2008; Snowball and others 2010) but due to the natural smoothing of palaeoclimate records, relatively low sampling resolution, chronological uncertainties, possible delays in ocean-atmospheric coupling and inconsistent responses of different proxy records to the assumed climate excursion, the records are difficult to compare and the total impact of the event has been difficult to study (Ojala and others 2008; Snowball and others 2010).

Annually laminated (varved) sediments enable precise and accurate dating which enables high temporal resolution studies to be carried out (Stanton and others 2010). Thus, varved sediments are a valuable tool in reconstructing rates of climatic and environmental change. Stanton and others (2010) undertook a detailed chronological study of a varved sediment sequence from Lake Kälksjön in west-central Sweden, a lake first studied by Zillén and others (2003). Snowball and others (2010) secured the Kälksjön varve chronology across the $8.2 \mathrm{ka}$ cooling event to the dendrochronologically derived calendar-year timescale using radiocarbon wiggle-matching. Snowball and others (2010) also transferred the Greenland icecore records onto the same timescale by means of ${ }^{10} \mathrm{Be}$ analysis following Muscheler and others (2004). They reconstructed a period of increased erosion, interpreted as caused by increased winter precipitation, between $8066 \pm 25$ and $7920 \pm$ 25 cal. y BP and drew the conclusion that aspects of climate related to precipitation changed abruptly in central Sweden at least five decades after the onset of the $8.2 \mathrm{ka}$ event over central Greenland (Snowball and others 2010).

In this study, we use the precise and accurate chronology of Kälksjön to look for evidence for abrupt ecological change in the lake in response to the abrupt 8.2 ka cooling; using detailed diatom analysis, we examine how the lake ecosystem responded to the supposed cooling and subsequent warming.

High-resolution palaeoecological reconstructions, such as the one presented in this article, can help constrain the timing and trajectory of local population changes to abrupt climate change (Williams and others 2011) and provide analogues of future changes in aquatic ecosystem structure and functioning caused by climate change. The records can also serve as a testing ground for critical-threshold detection tools of interest to global-change ecologists and ecosystem managers seeking reliable and 
advanced warning signs of impending regime shifts (Contamin and Ellison 2009; Williams and others 2011).

\section{MethodS}

\section{Site Description}

Lake Kälksjön $\left(60^{\circ} 09^{\prime} \mathrm{N}, 13^{\circ} 03^{\prime} \mathrm{E}\right)$ is located in the province of Värmland in west-central Sweden (Figure 1) and has an area of $0.4 \mathrm{~km}^{2}$. Maximum water depth is $14.2 \mathrm{~m}$, and the lake is located below the highest shoreline at an altitude of $98 \mathrm{~m}$ a.s.l. (Zillén and others 2003). The lake has four inflows entering from the east and north, and it drains through a stream to the west. The lake catchment covers $4 \mathrm{~km}^{2}$ and is dominated by managed boreal forest composed of spruce, pine and birch (Zillén and others 2003). Areas close to the lake margin are dominated by silty and clayey soils, and arable land occurs along the western shore of the lake. The remainder of the catchment is covered by sandy and silty till (Zillén and others 2003).

The study area was deglaciated around $10,000 \mathrm{cal}$. y. BP. The immediate surroundings of Lake Kälksjön, covered by fine-grained deposits, were initially part of Ancient Lake Vänern (Björck 1995), and the lake became isolated at c. $9000 \mathrm{cal}$. y. BP due to isostatic uplift (Zillén and others 2003). The lake provides an ideal sedimentary environment for the study of rapid environmental change, because the seasonal cycle of sedimentation is preserved in the lake in the form of biogenic-clastic varves (Stanton and others 2010; Snowball and others 2010). By counting annual layers, such records can be precisely dated, providing highly resolved quantitative microfossil stratigraphies for studies of environmental change (Renberg and Segerström 1981; Ojala 2001).

\section{Core Collection and Chronology}

Four parallel sediment profiles were collected from the lake ice during fieldwork in the late winters of 2002 and 2003 using a modified rod-operated Russian corer (Snowball and others 2010). Each profile consisted of a combination of five $1.5-\mathrm{m}$ long overlapping cores. The sediment profiles cover a sediment thickness of $6.75 \mathrm{~m}$ each and include the entire post-isolation period (Snowball and others 2010). The sediments are stored at $4^{\circ} \mathrm{C}$ in a cold humidified room at the Department of Geology, Lund University. An initial varve chronology for Lake Kälksjön sediments was established by Stanton and others (2010). Incremental seasonal layer counting was conducted from the sedimentwater interface. Historically dated atmospheric lead pollution isochrones were detected and established ages of palaeomagnetic secular variations were combined with the annual layer counts to produce

\section{A}

B

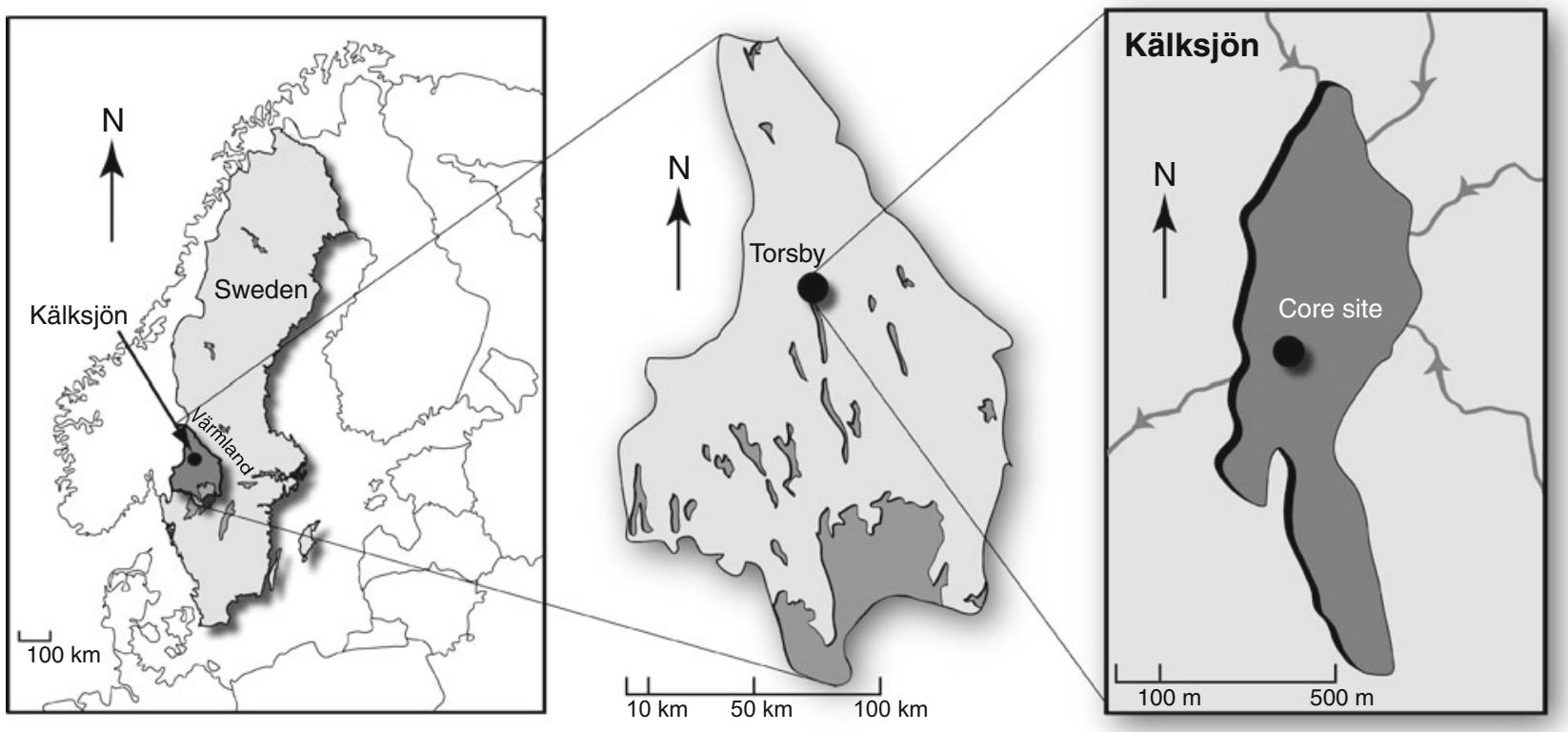

Figure 1. A Map of Scandinavia showing the location of the study site Lake Kälksjön, located in Värmland, west central Sweden. B Map of the province of Värmland. C Close-up map of the lake showing inlets, outlets and coring site (redrawn from Stanton and others 2010). 
a varve chronology that extended from the present day to the beginning of varve formation at $9193 \pm 186$ cal. y BP. The uncertainty of the varve chronology established by Stanton and others (2010) at $8000 \mathrm{cal}$. y BP was on the order of 150 years. Snowball and others (2010) reduced this uncertainty to 25 years through the radiocarbon wiggle-matching of a 400-year-long section of Stanton and others (2010) varve chronology that spanned the $8.2 \mathrm{ka}$ cooling event. This method finds the best statistical fit of a series of ${ }^{14} \mathrm{C}$ measurements to the calendar-year timescale that forms the basis of the IntCal04 radiocarbon calibration curve (Reimer and others 2004). Snowball and others (2010) also matched the GRIP and NorthGRIP ice-cores to the same absolute timescale by comparing ${ }^{10} \mathrm{Be}$ data and tree-ring $\Delta^{14} \mathrm{C}$. This procedure synchronized the Lake Kälksjön data and Greenland chronology ice-core data to the absolute timescale, without any dependency on changes in proxy-climate parameters. We emphasize that possible future changes to the tree-ringderived radiocarbon calibration curve will not affect the relative synchronization of the Kälksjön and Greenland ice-core data, although absolute ages might be altered.

\section{Diatom Analysis}

Continuous and quantitative samples for diatom analysis were taken using an aluminium tray of known volume. The sediments in the tray were cut into 78 samples under a macroscope using an Aniol electronic tree-ring measuring system in the Laboratory for Wood Anatomy and Dendrochronology at Lund University. They were cut to varves along the stratigraphic boundaries marking the division between winter and spring layers, and based on the wiggle matched varve chronology (Snowball and others 2010), the samples span the time period from c. 8500 to 7500 cal. y BP, with a resolution of 20 varves between c. $8500-8300 \mathrm{cal}$. y BP and c. $7700-7500$ cal. y BP and 10 varves in between. The diatom subsamples were freezedried and approximately $0.01 \mathrm{~g}$ of dry sediment was digested using the water-bath technique described by Renberg (1990) with digestion by $30 \% \mathrm{H}_{2} \mathrm{O}_{2}$ (Battarbee and others 2001). Diatom concentrations (valves $\mathrm{mg}^{-1}$ ) were determined by adding divinylbenzene spheres to the cleaned samples (Battarbee and Kneen 1982). Cleaned subsamples were dried onto cover slips and mounted onto microscope slides using Zrax $\quad(\mathrm{RI} \sim 1.7+)$. At least 400 diatom valves were counted in each subsample under a light microscope at $1000 \times$ using phase-contrast optics. Diatom taxonomy followed Krammer and LangeBertalot (1986, 1988, 1991a, b), Round and Bukhtiyarova (1996), Lange-Bertalot and Metzeltin (1996), Håkansson (2002), Houk and Klee (2004) and Siver and others (2005) and the diatoms were grouped according to their habitats into planktonic and periphytic life forms. In total, 16 planktonic and 78 periphytic taxa were identified. All diatom data are expressed as relative percentage abundances and for further numerical analyses these were reduced to 25 taxa with more than $3 \%$ relative abundance. The diatom accumulation rate (DAR), PCA of the planktonic and periphytic communities and Hill's N2 diversity index (Hill 1973) were calculated separately using all identified taxa.

\section{Pollen Analysis}

Pollen samples at intervals of $5-9 \mathrm{~cm}$ were prepared using standard methods (Berglund and Ralska-Jasiewiczowa 1986) with the addition of six lycopodium spike tablets for the calculation of pollen influx (Stockmarr 1971). Pollen grains were well preserved and between 800 and 1100 pollen were counted per sample. Selected pollen data are shown as influx (grains $\mathrm{cm}^{-2} \mathrm{y}^{-1}$ ).

\section{Organic Carbon Content}

The total carbon content of the same samples used for diatom analysis was analyzed using a Costech Instruments ECS 4010 elemental analyzer at the Department of Geology, Lund University. The subsamples were acid-washed in $10 \% \mathrm{HCl}$ to remove trace amounts of carbonates, rinsed with deionized water and freeze-dried prior to being homogenized and crushed with a mortar and pestle. Total inorganic carbon content is negligible (Snowball and others 2010) and the total carbon content is thus assumed to equal the total organic carbon (TOC) content of the sediments.

\section{Numerical Analysis}

The Stratigraphic diatom assemblage and production zones (DAZ) were determined through regression tree analysis (De'ath and Fabricius 2000) using the mvpart package (De'ath 2011) for the R statistical software (R Development Core Team 2011) in combination with change-point analysis (described below). The smallest tree within one standard error of the tree with the lowest cross-validation relative error was chosen, producing four zones. A detrended correspondence analysis (DCA) performed 
using the vegan package (Oksanen and others 2009 ) in $R$ revealed that the gradient length in the diatom data was short ( $<2$ SD units) and, therefore, principle component analysis (PCA) was performed on Hellinger transformed diatom data using the same package. Hellinger transformation preserves the Hellinger distances, a dissimilarity coefficient shown to have good properties for ecological data, between samples in the resulting PCA (Legendre and Gallagher 2001). One PCA axis was identified as explaining significant proportions of the variance in the stratigraphic data when compared to the broken stick (null) distribution (Jackson 1993). This axis explained $47 \%$ of the variance. Principle components analysis was also performed on the planktonic and periphytic communities separately. In both the analyses one axis was significant, and these axes explained $61 \%$ of the variance in the planktonic community and $45 \%$ of the variance in the periphytic community, respectively.

Total DAR, the proportion of planktonic to total DAR, and the first principal components of both the planktonic and the periphytic communities were analyzed for change points over time using a combination of abrupt step changes and piece-wise linear regressions (for details see Carstensen and Weydmann 2012). The abrupt step-change model has a discontinuity where the mean of the time series changes from one time step to another, whereas the piece-wise linear regression is continuous with changing slopes for different periods. Logarithmic and logistic transformations were applied to total DAR and the planktonic proportion of DAR, respectively, to achieve time series with normal distributions. The principal components were approximately normally distributed and thus were not transformed. An autoregressive term (AR(1)-process) for the error process was included in the change-point analyses to account for potential correlation in the time series, acknowledging that samples were not equidistantly distributed with time $(10,15,20$, or 25 years in-between samples) but were multiples of 5 years. This implied that if two observations were, for example, 15 years apart (that is, 3 lags), the autoregressive parameter would be raised to the power of 3. Thus, the autoregressive parameter described temporal correlation at a 5-year scale. The significance of the change-point models was assessed using likelihood ratio statistics, and the abrupt and piece-wise linear models were compared using Bayes Information Criterion (BIC). Non-significant slopes in the piece-wise linear model were set to zero. The change-point detection analyses were carried out using PROC MODEL in SAS v.9.2.

\section{RESUltS}

The studied sediment section has been subdivided into four zones, which have different diatom community structures: the bottom zone is dominated by periphytic diatoms, the next is defined by the appearance of Puncticulata radiosa (Lemmerman) Håkansson 2002, the third encompasses a shift to a higher lake productivity and the top zone records a shift in dominant taxa from periphyton to plankton. All absolute ages that refer to Kälksjön hereafter have an uncertainty of \pm 25 years.

\section{DAZ 1 (8500-8206 cal. y BP)}

Zone 1, the base of the studied section, is dominated by periphytic diatoms, which make up 55$80 \%$ of the total diatom assemblage (Figure 2). The most abundant periphytic forms are Planothidium frequentissimum (Lange-Bertalot) Round and Bukhtiyarova 1996, and small taxa in the Fragilariaceae, such as Staurosira construens (Ehr.) Williams and Round 1987, Staurosirella pinnata (Ehr.) Williams and Round 1988, and Pseudostaurosira brevistriata (Grunow in Van Heurk) Williams and Round 1987. In this zone the DAR, which is an estimate of productivity and/or preservation of diatoms, is relatively low, with a $\mathrm{DAR}_{\text {total }}$ of $80-200 \times 10^{4}$ valves $\mathrm{cm}^{-2} \mathrm{y}^{-1}$, divided into $\mathrm{DAR}_{\text {periphyton of }}$ $40-120 \times 10^{4}$ valves $\mathrm{cm}^{-2} \mathrm{y}^{-1}$ and DAR plankton of $15-80 \times 10^{4}$ valves $\mathrm{cm}^{-2} \mathrm{y}^{-1}$ (Figure 3). The samples plot together in the upper left quadrant of the PCA diagram (Figure 4), where the small Fragilariaceae and other periphytic taxa show their highest abundances.

The pollen record shows a domination of Betula and Pinus during this time period with an increase in total pollen influx from around 8400 cal. y BP, determined by Betula and Pinus, with Pinus expanding slightly earlier than Betula. A subsequent decrease in total pollen influx was recorded at c. 8260 cal. y BP (Figure 3).

\section{DAZ 2 (8206-8036 cal. y BP)}

Periphytic diatoms dominate this zone, as well, and make up $60-75 \%$ of the total diatom assemblage (Figure 2). The periphyton is still dominated by Planothidium frequentissimum and small Fragilariaceae, but the planktonic assemblage is characterized by the sudden appearance and rise in abundance of Puncticulata radiosa, a centric planktonic diatom that makes up $60-70 \%$ of the plankton (Figure 2). The appearance of Puncticulata radiosa defines this DAZ. Other abundant planktonic species are Cyclotella 

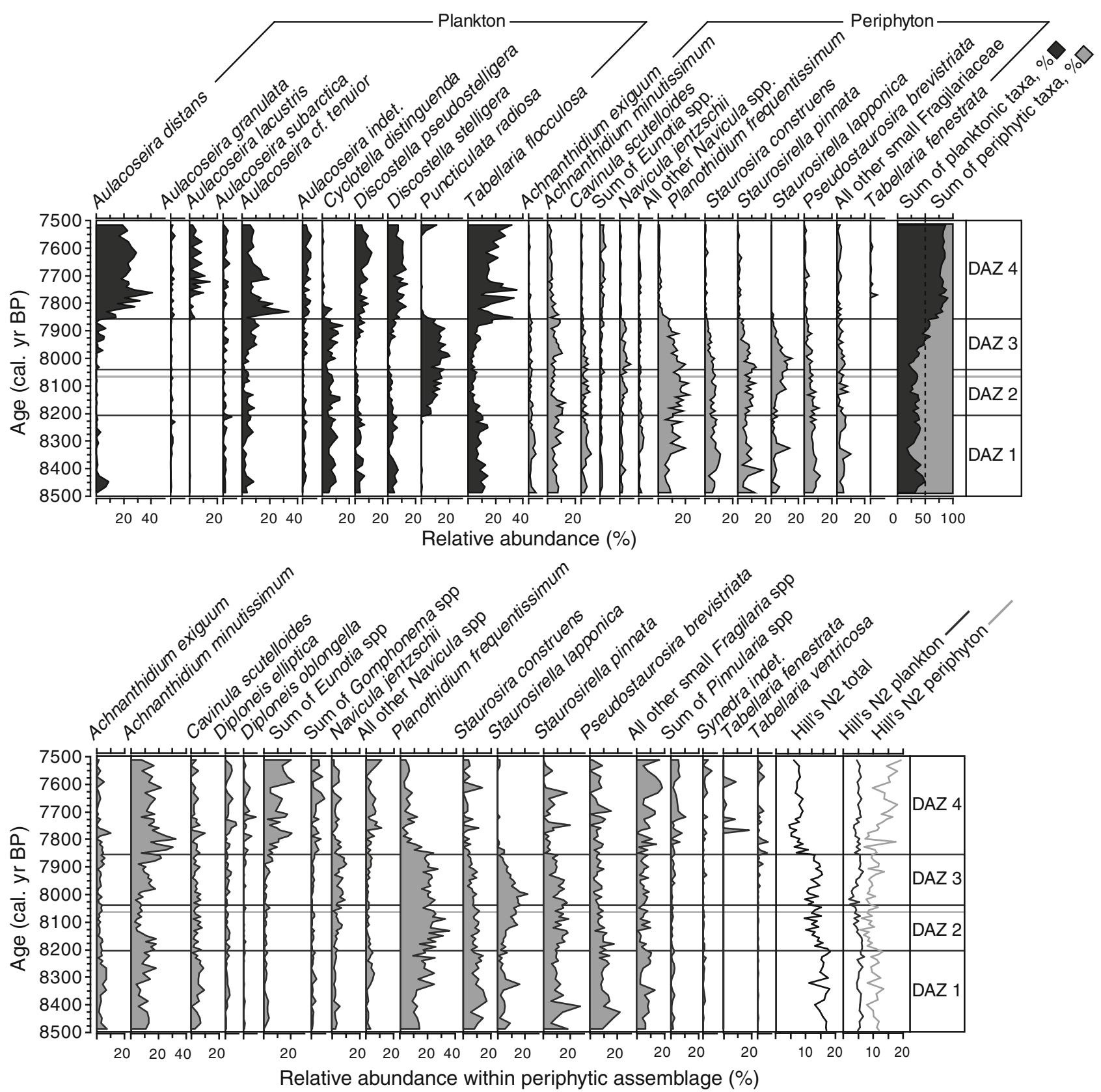

Figure 2. Diatom stratigraphy of the major $(>3 \%)$ taxa in Lake Kälksjön as relative abundance (\%), diatom assemblage and production zones (DAZ), and proportion of plankton and periphyton (\%). Major (>5\%) periphytic taxa as relative abundance $(\%)$ within the periphytic community and Hill's N2 for all species as well as plankton and periphyton, respectively. Grey line z-varve at 8066 cal. y BP.

distinguenda Hustedt 1927 and Tabellaria flocculosa (Roth) Kützing 1844 [Strain IIIp sensu Koppen]. DAR values remain relatively low throughout this zone, with $\mathrm{DAR}_{\text {total }}$ between 50 and $175 \times 10^{4}$ valves $\mathrm{cm}^{-2} \mathrm{y}^{-1}$, reaching a minimum of $39 \times 10^{4}$ valves $\mathrm{cm}^{-2} \mathrm{y}^{-1}$ at c. $8040 \mathrm{cal}$. y BP (Figure 3). At the same time, there is a drop in the TOC content from c. 9 to $6 \%$ (Figure 3). The samples belonging to this zone plot on the left side of the ordination diagram (Figure 4) and the change on PCA axis 2 is heavily influenced by the appearance of Puncticulata radiosa, which has its highest abundance in the lower left quadrant.

The total pollen influx values are low and relatively stable, fluctuating between 24000 and 28000 grains $\mathrm{cm}^{-2} \mathrm{y}^{-1}$ throughout this period, with only minor variations in Betula and Pinus percentages (not shown). 

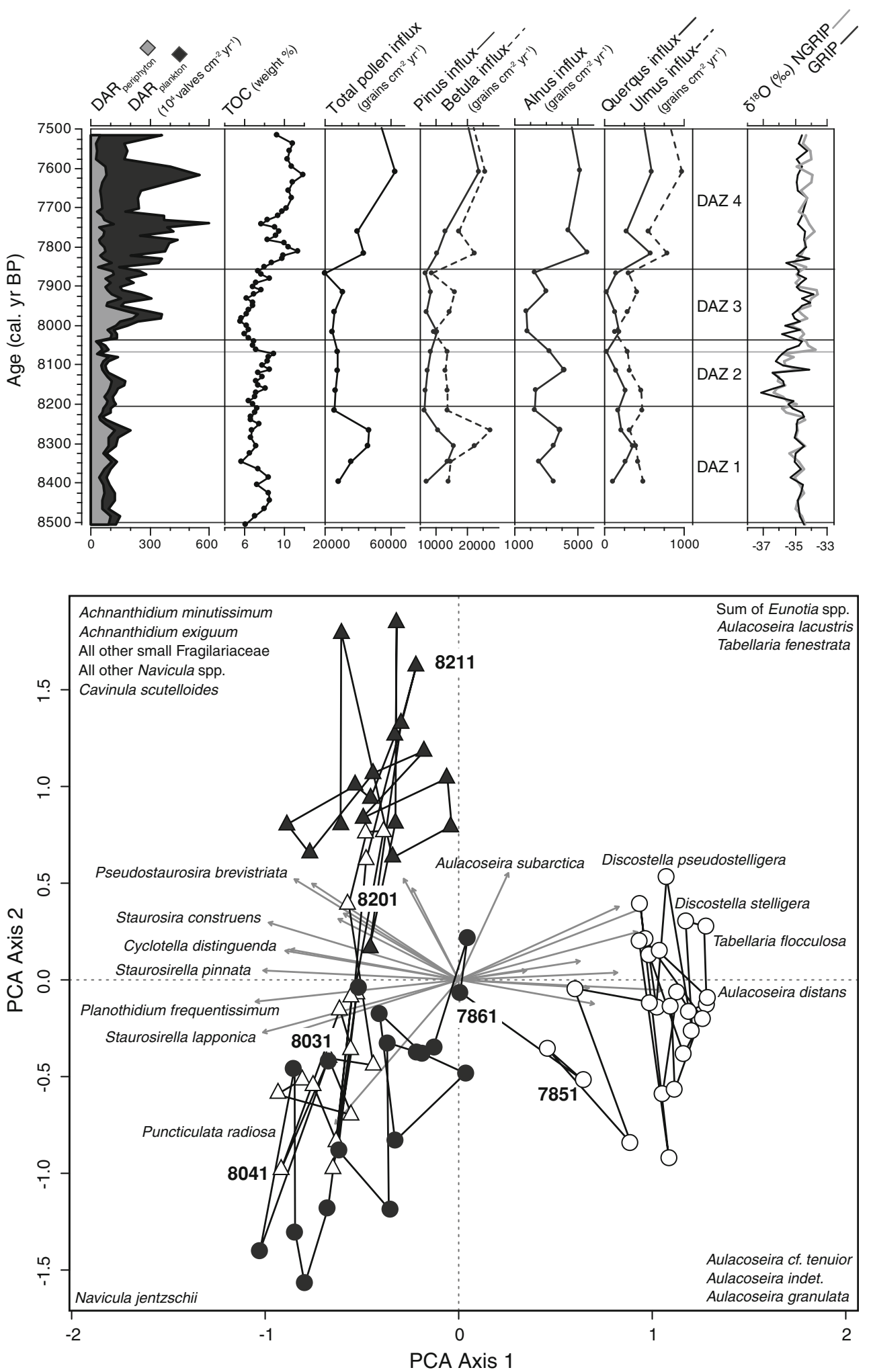

Figure 3. Diatom accumulation rates (DAR), weight \% total organic carbon (TOC), total pollen influx and influx of selected tree pollen, and $\delta^{18} \mathrm{O}$ records from the GRIP and NorthGRIP ice-cores (Rasmussen and others 2006). The GICC05 timescale was synchronized to the IntCal04 tree-ring timescale (see Snowball and others 2010). Diatom assemblage and production zones (DAZ) as in Figure 2.

Figure 4. PCA ordination diagram of diatom samples and taxa with an abundance greater than $3 \%$. Samples belonging to DAZl (8500-8206 cal. y $\mathrm{BP})$ are shown as black triangles, DAZ2 (82068036 cal. y BP) as white triangles, DAZ3 (80367856 cal. y BP) as black circles and DAZ4 (78567500 cal. y BP) as white circles. Crowded taxon labels are shown in their respective quadrants of occurrence.

\section{DAZ 3 (8036-7856 cal. y BP)}

This diatom assemblage is very similar to DAZ 2, with Puncticulata radiosa, C. distinguenda and T. flocculosa as the dominant planktonic species and
Planothidium frequentissimum and small Fragilariaceae dominating the periphyton (Figure 2). The proportion of periphyton is approximately equal to plankton, with plankton reaching $50-55 \%$ towards 

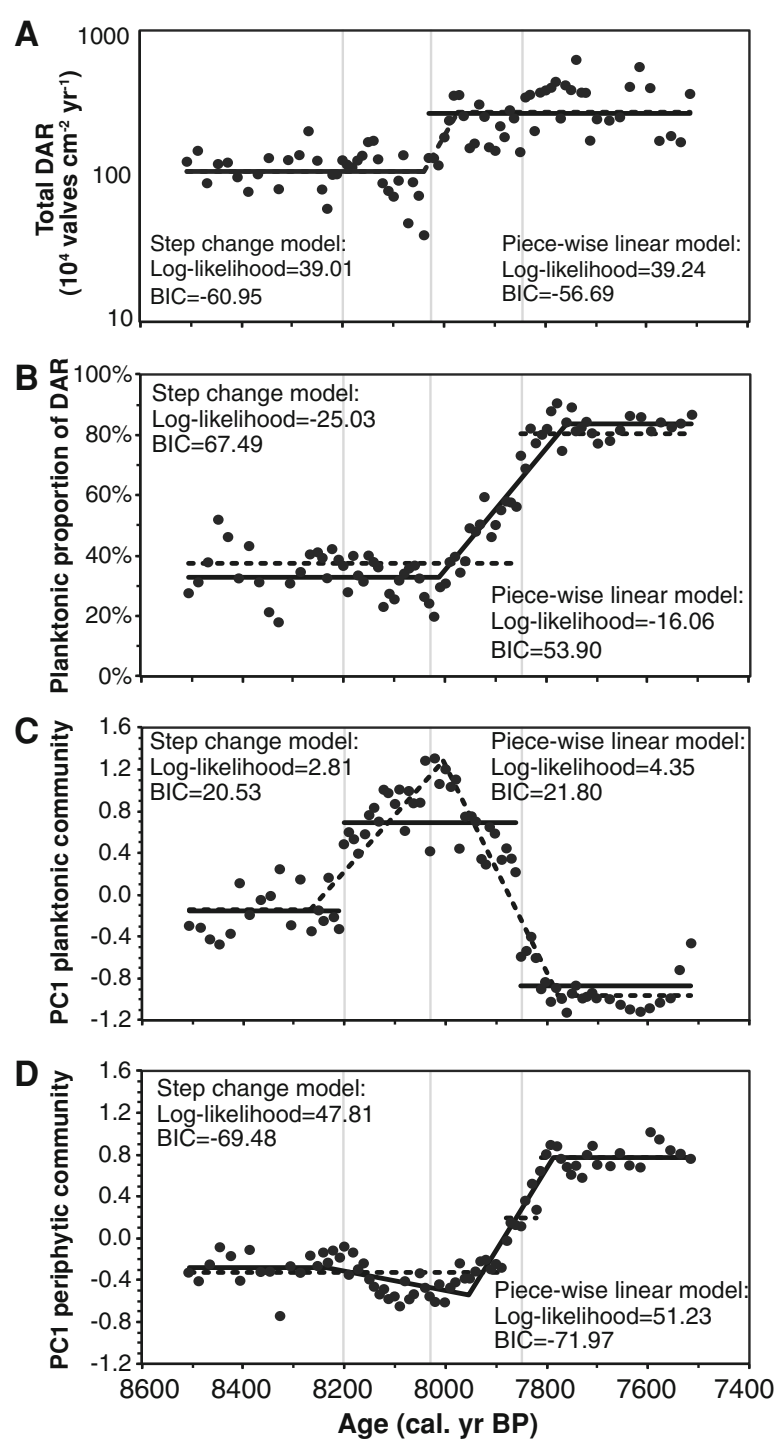

Figure 5. Time series of $\mathbf{A}$ the total diatom accumulation rate, $\mathbf{B}$ the planktonic proportion of the total diatom accumulation rate, $\mathbf{C}$ first principle component of the planktonic community, and D first principle component of the periphytic community. Log-likelihood and BIC values are given for the different models. The optimal change-point models (assessed by the lowest (BIC)) are shown with solid lines, and the alternative less suitable models with dashed lines. Grey lines in accordance with DAZ as in Figure 2.

the top of the zone. The main characteristics of the zone are the increases around $7990 \mathrm{cal}$. y BP in both $\mathrm{DAR}_{\text {plankton }}$ and $\mathrm{DAR}_{\text {periphyton }}$ up to a DAR total of $360 \times 10^{4}$ valves $\mathrm{cm}^{-2} \mathrm{y}^{-1}$ at c. 7970 cal. y BP (Figures 3, 5A, B). The periphytic accumulation rate reaches a peak of $240 \times 10^{4}$ valves $\mathrm{cm}^{-2} \mathrm{y}^{-1}$ at this time and then drops to the same low levels as in DAZ 1 (Figure 3). The DAR plankton reaches high levels at the same time and then remains high, albeit fluctuating throughout the sequence (Figure 3).

The samples plot in the lower left quadrant of the PCA diagram (Figure 4). The samples from the bottom of the zone are difficult to distinguish from the samples of DAZ 2, whereas the samples move to the right on PCA axis 1 further up in the zone. Because changes in DAR, the defining characteristic of DAZ 3, are not represented in the PCA, it is not surprising that the two groups are quite similar in the ordination diagram.

TOC values are low at the beginning and middle of this zone, increasing to c. $8 \%$ at the top. Total pollen influx values remain low throughout the zone, reaching their lowest values of 20300 grains $\mathrm{cm}^{-2} \mathrm{y}^{-1}$ at c. $7890 \mathrm{cal}$. y BP (Figure 3), although Quercus influx values are already showing some recovery slightly prior to the other taxa.

\section{DAZ 4 (7856-7500 cal. y BP)}

At c. 7850 cal. y BP, there is a substantial shift in the diatom assemblage of Lake Kälksjön, with planktonic diatoms becoming completely dominant. Planktonic species make up $70-90 \%$ of the total diatom assemblage in this upper part of the record and are mainly composed of Aulacoseira taxa. A. distans (Ehr.) Simonsen 1979 is the dominant, with an abundance of up to $50 \%$ of the planktonic species (Figure 2). Other important planktonic species are T. flocculosa and small centric D. stelligera (Cleve et Grunow) Houk and Klee 2004 and D. pseudostelligera (Hustedt) Houk and Klee 2004 (Figure 2). Puncticulata radiosa, which dominated two previous assemblage zones, disappears at the beginning of this zone and is not present in any large quantities, although it returns at the top of the sequence. In the periphytic assemblage, Planothidium frequentissimum decreases in abundance along with the small Fragilariaceae, and a slightly more diverse flora develops, with Achnanthidium minutissimum (Kützing) Czarnecki 1994 and small Eunotia species increasing in abundance. Accumulation rates are relatively high, with $\mathrm{DAR}_{\text {total }}$ fluctuating around $150-630 \times 10^{4}$ valves $\mathrm{cm}^{-2} \mathrm{y}^{-1}$. $\mathrm{DAR}_{\text {periphyton }}$ remains stable at the same low values as in DAZ 1, whereas $\mathrm{DAR}_{\text {plankton }}$ is varying between 75 and $500 \times 10^{4}$ valves $\mathrm{cm}^{-2} \mathrm{y}^{-1}$ (Figure 3). The samples plot on the right side of the PCA diagram and are clearly set apart from the earlier samples (Figure 4).

The TOC content rises at the beginning of the zone and reaches a maximum towards the top (Figure 3). At c. 7860, the pollen influx values increase, with Betula and Pinus as the most 
common taxa, but the deciduous trees (Alnus, Quercus, Ulmus and Corylus) also show increasing abundances throughout the zone (Figure 3).

\section{Change Points Over Time}

The step-change and the piece-wise linear models were equally good in describing the total DAR variations (Figure 5A), but the step-change model used one parameter less, resulting in a lower BIC, and was therefore considered more suitable to describe the trends in total DAR. The step-change model suggested that $\mathrm{DAR}_{\text {total }}$ increased abruptly from $107 \times 10^{4}$ to $269 \times 10^{4}$ valves $\mathrm{cm}^{-2} \mathrm{y}^{-1}$ between $8041 \pm 25$ and $8031 \pm 25 \mathrm{cal}$. y BP. Conversely, the piece-wise linear model was much better at describing the trends in the DAR proportion of planktonic diatoms (Figure 5B). The piecewise linear model suggested a constant proportion of $33 \%$ planktonic diatoms that increased to $84 \%$ over a 250-year period between $8012 \pm 33$ and $7762 \pm 24$ cal. y BP, that is, almost immediately after the abrupt step change in $\mathrm{DAR}_{\text {total }}$.

Changes were also apparent at the community level. The first principal component of the plankton community reflects the dominance of Puncticulata radiosa at positive values and small Discostella spp. and $A$. distans at negative. The axis was best described with a step-change model, suggesting abrupt changes in the planktonic community around both $8201 \pm 25$ and $7851 \pm 25$ cal. y BP (Figure 5C). A piece-wise linear model was selected for the first principal component of the periphyton community showing a stable community, with Fragilariaceae and Planothidium frequentissimum as the main contributors to the negative axis values, before $8237 \pm 102 \mathrm{cal}$. y BP. The community changed slightly over the following 300 years and then shifted more drastically over the next 150 years to positive axis values that are associated mainly with small Eunotia spp., attaining a new and stable community after $7787 \pm 12$ cal. y BP (Figure 5D). For all the four models, the 5-year correlation was estimated to between 0.64 and 0.74 . Consequently, the 10-year correlation was the square of the AR(1) parameter estimates, the 15-year correlation was the cube and so forth.

\section{Discussion}

Changes in diatom composition and abundance provide information on the prevailing conditions in Lake Kälksjön and its catchment in the centuries before and after the $8.2 \mathrm{ka}$ event. The lake formed approximately 9000 years ago (Stanton and others
2010) and from c. 8500 to 8200 cal. y BP periphytic diatoms, in particular, small Fragilariaceae, dominated the diatom assemblage (Figure 6A). These species are common in lake sediments deposited in newly deglaciated terrain (Smol 1983) and are considered as adaptable and cosmopolitan (Lotter and others 2000). They have short life spans and are common in lakes with a prolonged ice cover and a short ice-free season (Lotter and Bigler 2000; Jones and Birks 2004). Rising pollen influx values indicate developing vegetation in the catchment from c. 8500 cal. y BP, consisting mainly of birch and pine forest. The presence of heavily silicified Aulacoseira species in the planktonic diatom assemblage suggests wind-induced turbulence and sustained water-column mixing, conditions that are required by the heavy Aulacoseiras to stay buoyant (Jones and others 2011).

At c. 8200 cal. y BP Puncticulata radiosa, a centric planktonic diatom, appeared (Figure 6B). This is a species indicative of cold summer conditions (Rimet and others 2009; Rioual and others 2006). It tolerates low light and low nutrient levels and is characterized by its fast growth (Rimet and others 2009). Change-point analysis of the planktonic community shows that there is an abrupt and significant change on the first principle component at c. 8200 cal. y BP (Figure 5C). PCl can be interpreted as a climate proxy, with species such as Puncticulata radiosa, indicating cold summer conditions at positive values and species indicative of warmer stratified summer conditions, for example, D. stelligera and D. pseudostelligera (Rühland and others 2008; Enache and others 2011), at negative values. The overall DAR in the lake was still low, and the dominating periphytic community was made up of Fragilariaceae, which, in combination with the change in planktonic species composition, suggest weak stratification during the open-water period and deep water-column mixing. Low pollen influx values indicate less vegetation in the catchment and/or a stressed terrestrial environment. Comparable declines in tree pollen influx (Corylus, Alnus, Tilia, Ulmus) were recorded in Lake Rõuge, Estonia (Veski and others 2004) between c. 8250 and 8150 cal. y BP but, in contrast to our results, a simultaneous increase in Betula influx was found. This was attributed to a higher tolerance of Betula to lowered temperatures during the flowering period in early spring. An increase in Betula while other tree taxa declined (excepting Pinus) was also recorded between 8200 and 8000 cal. y BP at Højby Sø, Denmark (Hede and others 2010), together with an indication of cooler summer temperatures. The changes in our diatom and pollen records can 


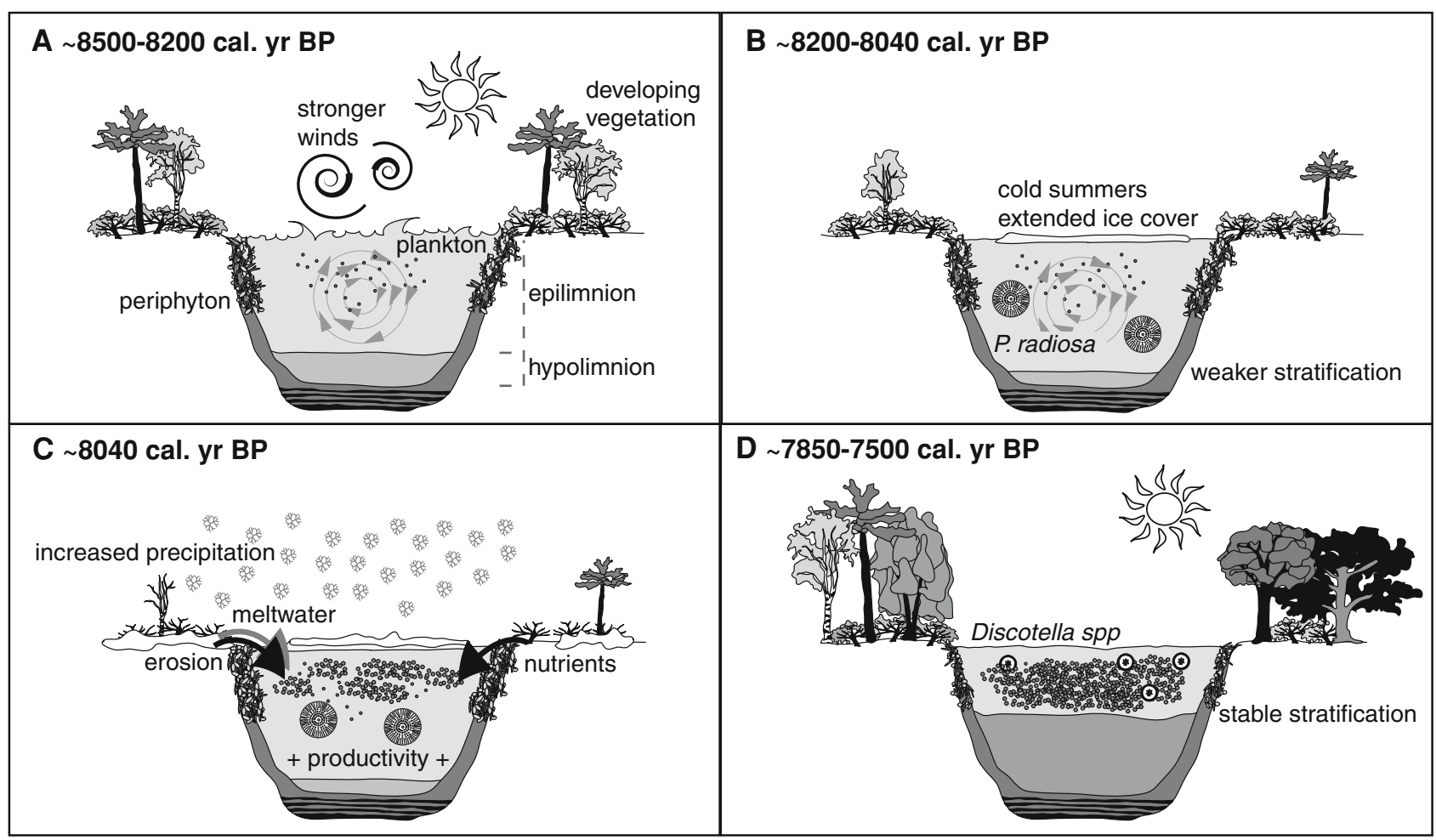

Figure 6. Illustration of the hypothetical development of Lake Kälksjön across the 8.2 ka event.

be connected to the $8.2 \mathrm{ka}$ event as defined by oxygen isotope records from the Greenland icecores (Kobashi and others 2007). Kobashi and others (2007) concluded that the event started at $8175 \pm 30$ years BP and that it took less than 20 years to reach the coldest period, with a cooling of $3.3 \pm 1.1^{\circ} \mathrm{C}$ in central Greenland. In general, Northern Hemisphere conditions were cooler, drier and perhaps windier during the event (Alley and Agustsdottir 2005), and many palaeoclimate records from various parts of Europe suggest that it was predominantly a winter and spring event (for example, Alley and Agustsdottir 2005; Wiersma and Renssen 2006; Seppä and others 2007). In Arctic and high-altitude lakes, cold and long winters with thick ice cover and delayed ice break-up in spring lead to a higher abundance of periphytic diatoms as compared to planktonic (for example, Lotter and Bigler 2000), and these observations provide a model for shifts in the diatom community at the 8.2 ka event. Many Fennoscandian lakes, for example, Lake Nautajärvi in southern central Finland, showed a shift from planktonic species dominance to more littoral species dominance at the $8.2 \mathrm{ka}$ cooling (Ojala and others 2008) and in a small west Greenland lake an abrupt shift from a planktonic to a periphytic community, including the sudden disappearance of Cyclotella (Puncticulata) radiosa, took place at the same time (Andersen and others 2009). The ecological response to the $8.2 \mathrm{ka}$ cooling event is somewhat different in Lake Kälksjön: here a prolongation of the early, postglacial, Fragilariaceae dominated conditions occurred, and planktonic diatom composition changed abruptly to taxa more tolerant of cold conditions, weak stratification and deep watercolumn mixing in the summer months. The differential response of lakes in different locations points to the role of local conditions, such as vegetation and morphometry, in mediating the nature of limnological response to a given environmental forcing.

Snowball and others (2010) reconstructed a period of enhanced erosion in the catchment of Lake Kälksjön from 8066 to 7920 cal. y BP. They argued that this anomalous period of erosion was caused by increased winter precipitation and higher spring meltwater discharge, increasing the input of minerogenic matter into the lake. This process caused the formation of the $z$-varve at $8066 \mathrm{cal}$. y BP (Figure 2): a varve with a distinctly thick mineral spring layer, which marks a transition from relatively organic-rich to relatively mineral-rich sediments (Snowball and others 2010). The timing of this coincides with a short period of increased global methane emissions and, by extension, 
warming and wetting as reconstructed by Kobashi and others (2007) at c. $8070 \mathrm{BP}$. This short methane spike is also evident in the Greenland temperature record, which suggests that the short-term warmer and wetter event was a large-scale climatic excursion (Kobashi and others 2007). The Lake Kälksjön data suggest an increase in nutrient supply associated with elevated erosion and a resultant increase in lake productivity (Figure 6C). This is evident in the DARs, which show a doubling in 5-10 years time, centered at c. 8040 cal. y. BP (Figure 3 and $5 \mathrm{~A})$. The abrupt step-change character of the trend in total DARs, however, suggests an abrupt increase in nutrient input into the lake rather than a gradual increase, which supports the hypothesis of a major erosion event (initially recorded as the $z$-varve) in the catchment at c. $8060 \mathrm{cal}$. y BP. At this time, pollen influx had already been low for around 200 years, possibly indicating decreased vegetation cover and more exposed soils. The diatom community structure did not change significantly during this time period, suggesting that the overall climate was still cold.

PCA and regression tree analysis data (Figures 2 and 4) show that the diatom assemblage of DAZ 4 (7856-7500 cal. y BP) differs significantly from the rest of the sequence, which implies an important environmental shift in the lake (Figure 6D). The lake became plankton dominated, and within the planktonic community Puncticulata radiosa virtually disappeared, accompanied by an increase in lowalkalinity species such as $A$. distans. The planktonic community was dominated by Aulacoseira taxa, which suggests ample supplies of dissolved silica and nutrients, high turbulence keeping these heavy diatoms afloat (Ojala and others 2008; Panizzo and others 2008) and prolonged open-water seasons (Lund 1955). Also important were small Discostella species (D. stelligera and D. pseudostelligera), which are characteristic of stable lake stratification (Rühland and others 2008; Enache and others 2011), and T. flocculosa, which often increases with initial lake eutrophication (Anderson and others 1995). Taken together, the diatom assemblage suggests that the lake was stratified during summer; favoring the Discostellas, but that Aulacoseira taxa were abundant during the isothermal period in spring (for example, Rautio and others 2000). An alternative explanation, given that the samples are aggregates of 10 or 20 years, is that limnological conditions varied from year to year in this interval, with conditions more favorable for Discostella species in some years and those favoring Aulacoseira during other years. In general, rises in Cyclotella abundance indicate warming-induced lakewater changes and inferred higher summer temperatures in northern Sweden at this stage (Rosen and others 2000; Bigler and Hall 2002; Bigler and others 2006). The shift from Fragilariaceae to Cyclotella, and other planktonic taxa, in Lake Kälksjön mirrors data from Lake Vuolep Njakajaure in northern Sweden (Bigler and others 2006), where an appearance and dominance of planktonic Cyclotella taxa was recorded at c. 7800 cal. y BP. A similar pattern also has been observed in many Arctic lakes in response to recent climate warming ( $\mathrm{Smol}$ and others 2005; Rühland and others 2008). The change within the planktonic community was abrupt at c. $7850 \mathrm{cal}$. y BP, whereas there was a more gradual change within the periphyton (Figure 5C, D). The periphytic community changed over a period of c. 150 years centered at c. $7870 \mathrm{cal}$. y BP, and a more diverse flora replaced the Fragilariaceae (Figure 2). The pollen data suggest that the vegetation in the catchment recovered, with rapidly increasing abundance of tree pollen (mainly birch and pine) after a distinct low at c. 7860 cal. y BP. The appearance of $A$. distans, a diatom indicative of increased humic contents of lake waters (Eloranta 1986; Turkia and others 1998), was probably favored by the development of organicrich soils in the catchment. Alnus (alder) also expanded at about the same time (c. 7850) in Lake Vuolep Njakajaure (Bigler and others 2006). In this case, the authors suggested that the establishment of Alnus enhanced the high in-lake productivity because Alnus is able to fix atmospheric nitrogen, and as a result nitrogen concentrations in soils and near-shore waters probably increased (Bigler and others 2006). In newly deglaciated lakes in Alaska (Engstrom and others 2000; Fritz and others 2004), the establishment of Alnus has major impacts on lake chemistry and nutrient availability with pronounced consequences for diatom assemblages.

Lake Kälksjön displays two distinct periods of abrupt ecological change during the investigated time period: the change in accumulation rate at $\mathrm{c}$. $8040 \mathrm{cal}$. y BP and the shift to planktonic dominance at c. 7850 cal. y BP. In this article, we use "abrupt change" in the broad phenomenological sense described by Williams and others (2011): "abrupt change occurs when one or more variables in a system rapidly jump from one state to another, at rates that are rapid relative to background rates". A "regime shift" has occurred if the new state is persistent (Folke and others 2004; Williams and others 2011). Regime shifts have been described as sudden and large events that lead to rapid ecosystem reconfiguration (for example, Lees and others 2006; Andersen and others 2009; Williams and 
others 2011), hence we choose to describe both periods as regime shifts.

Both shifts are rapid, but the second one is more complex with different parameters involved. The shift at c. 8040 cal. y BP is an abrupt step change occurring over just 5-10 years (Figure 5A). The rapid increase in nutrient supply associated with elevated catchment erosion led to increased diatom productivity in the lake, but not a change in species composition. In lakes in the high Arctic, increased nutrient supply commonly does not lead to changes in diatom species assemblage (Douglas and Smol 2000; Smol and Douglas 2007) but has been inferred to affect the diatom productivity (Antoniades and others 2011), as seen here in Kälksjön. The change in species composition at c. 7850 cal. y $\mathrm{BP}$ is complex and can be seen as a successive change from periphytic to planktonic diatom dominance, accompanied by a continued increase in planktonic DAR, over a 250-year period (Figures 3, 5B). Within the planktonic community, however, the shift from taxa indicative of colder conditions to those indicating warm was abrupt and took place over 5-10 years around $7850 \mathrm{cal}$. y $\mathrm{BP}$ (Figure 5C), whereas the change in periphytic taxa to a more diverse community took c. 150 years (Figure 5D) from c. 7950 to 7800 . The change in species composition was most likely caused by climate warming leading to stable lake stratification, shallower mixing depth and increased nutrient recycling, which favored planktonic species over the periphyton.

Both regime shifts are examples of extrinsic changes where strong and rapid forcing (nutrient input and climate, respectively) is the primary causative agent of the abrupt ecological change (Williams and others 2011). They are also both examples of regime shifts resulting from smooth pressure-status relationships, where an abrupt change in external forcing leads to an equally abrupt ecosystem change: the regime shift in the driver is linearly mediated to the ecosystem state (Andersen and others 2009). However, the abrupt shift within the planktonic community can be described as a threshold-like or tipping-point regime shift: the change in driver (climate warming) does not seem to affect the planktonic community until a critical threshold is reached, at which point the system state changes rapidly (Andersen and others 2009).

These kinds of rapid ecosystem changes caused by extrinsic factors have been described before. They have, for example, been found at the Younger Dryas cooling and subsequent warming (for example, Ammann and others 2000; Birks and
Ammann 2000; Yu 2007; Steffensen and others 2008; Gonzales and Grimm 2009; Williams and others 2011). The regime shifts in Lake Kälksjön are also consistent with the changes described by Smol and others (2005) and Rühland and others (2008), who have observed that recent climate warming caused an increase in planktonic diatoms, such as Cyclotella species, and a compensatory decrease in small periphytic species in several Arctic lakes. However, although these studies established that abrupt changes occurred during the time periods investigated, the shifts were only evaluated using qualitative assessments, and no inferential analyses were made. In this article, we demonstrate that using change-point models can help detect, quantify and test for regime shifts in palaeoecological data, and we propose that other regime shift studies can benefit from this approach. A key element for rigorous quantitative methods, however, is high sampling resolution and precise chronological control.

\section{ACKNOWLEDGMENTS}

This work was supported by the Swedish Research Council (Vetenskapsrådet) and The Royal Physiographical Society in Lund (Kungliga Fysiografiska Sällskapet i Lund). We would like to thank Raimund Mucheler for help with the timescale and treatment of ice-core data, Dan Hammarlund and Tania Stanton for constructive comments on the manuscript and Kathleen Rühland for helpful comments on the diatom stratigraphy. Two anonymous reviewers are thanked for their valuable comments and suggestions.

\section{OPEN ACCESS}

This article is distributed under the terms of the Creative Commons Attribution License which permits any use, distribution, and reproduction in any medium, provided the original author(s) and the source are credited.

\section{REFERENCES}

Alley RB, Mayewski PA, Sowers T, Stuiver M, Taylor KC, Clark PU. 1997. Holocene climatic instability: a prominent, widespread event 8200 yr ago. Geology 25:483-6.

Alley RB, Agustsdottir AM. 2005. The $8 \mathrm{k}$ event: cause and consequences of a major Holocene abrupt climate change. Quatern Sci Rev 24:1123-49.

Ammann B, Birks HJB, Brooks SJ, Eicher U, von Grafenstein U, Hofmann W, Lemdahl G, Schwander J, Tobolski K, Wick L. 2000. Quantification of biotic responses to rapid climatic changes around the Younger Dryas-a synthesis. Palaeogeogr Palaeoclimatol Palaeoecol 159:313-47. 
Andersen T, Carstensen J, Hernandez-Garcia E, Duarte CM. 2009. Ecological thresholds and regime shifts: approaches to identification. Trends Ecol Evol 24:49-57.

Anderson N, Renberg I, Segerström U. 1995. Diatom production responses to the development of early agriculture in a boreal forest lake-catchment (Kassjön, Northern Sweden). J Ecol 83: 809-22.

Antoniades D, Michelutti N, Quinlan R, Blais JM, Bonilla S, Douglas MSV, Pienitz R, Smol JP, Vincent WF. 2011 . Cultural eutrophication, anoxia, and ecosystem recovery in Meretta Lake, High Arctic Canada. Limnol Oceanogr 56:639-50.

Barber D, Dyke A, Hillaire-Marcel C, Jennings AE, Andrews JT, Kerwin MW, Bilodeau G, McNeely R, Southon J, Morehead MD, Gagnon JM. 1999. Forcing of the cold event of 8,200 years ago by catastrophic drainage of Laurentide lakes. Nature 400:344-8.

Battarbee RW, Kneen MJ. 1982. The use of electronically counted microspheres in absolute diatom analysis. Limnol Oceanogr 27:184-8.

Battarbee RW, Jones VJ, Flower RJ, Cameron NG, Bennion H, Carvalho L, Juggins S. 2001. Diatoms. In: Smol JP, Birks HJB, Last WM, Eds. Tracking environmental change using lake sediments, vol 3: terrestrial, algal, and siliceous indicators. Dordrecht: Kluwer. p 155-202.

Beaugrand G. 2004. The North Sea regime shift: evidence, causes, mechanisms and consequences. Prog Oceanogr 60:245-62.

Berglund BE, Ralska-Jasiewiczowa M. 1986. Pollen analysis and pollen diagrams. In: Berglund BE, Ed. Handbook of Holocene Palaeoecology and Palaeohydrology. Chichester: Wiley. p 455-84.

Bigler C, Barnekow L, Heinrichs ML, Hall RI. 2006. Holocene environmental history of Lake Vuolep Njakajaure (Abisko National Park, Northern Sweden) reconstructed using biological proxy indicators. Veg History Archaeobot 15:309-20.

Bigler C, Hall R. 2002. Diatoms as indicators of climatic and limnological change in Swedish Lapland: a 100-lake calibration set and its validation for palaeoecological reconstructions. J Paleolimnol 27:97-115.

Birks H, Ammann B. 2000. Two terrestrial records of rapid climatic change during the glacial-Holocene transition $(14,000-$ 9,000 calendar years BP) from Europe. Proc Nat Acad Sci USA 97:1390-4.

Björck S. 1995. A review of the history of the Baltic Sea, 13.08.0 ka BP. Quatern Int 27:19-40.

Carstensen J, Weydmann A. 2012. Tipping Points in the Arctic: eyeballing or Statistical Significance? Ambio 41:34-43.

Clarke G, Leverington D, Teller J, Dyke A. 2004. Paleohydraulics of the last outburst flood from glacial Lake Agassiz and the 8200 BP cold event. Quatern Sci Rev 23:389-407.

Collie J, Richardson K, Steele J. 2004. Regime shifts: can ecological theory illuminate the mechanisms? Prog Oceanogr 60: 281-302.

Conley DJ, Carstensen J, Vaquer-Sunyer R, Duarte CM. 2009. Ecosystem thresholds with hypoxia. Hydrobiologia 629:21-9.

Contamin R, Ellison AM. 2009. Indicators of regime shifts in ecological systems: what do we need to know and when do we need to know it? Ecol Appl 19:799-816.

Daley TJ, Thomas ER, Holmes JA, Street-Perrott FA, Chapman MR, Tindall JC, Valdes PJ, Loader NJ, Marshall JD, Wolff EW, Hopley PJ, Atkinson T, Barber KE, Fisher EH, Robertson I, Hughes PDM, Roberts CN. 2011. The 8200 yr BP cold event in stable isotope records from the North Atlantic region. Global Planet Change 79:288-302.
De'ath G. 2011. mvpart: multivariate partitioning R package version 1.4-0. http://www.r-project.org/.

De'ath G, Fabricius K. 2000. Classification and regression trees: a powerful yet simple technique for ecological data analysis. Ecology 81:3178-92.

Dearing JA. 2008. Landscape change and resilience theory: a palaeoenvironmental assessment from Yunnan, SW China. Holocene 18:117-27.

Douglas M, Smol J. 2000. Eutrophication and recovery in the High Arctic: Meretta Lake (Cornwallis Island, Nunavut, Canada) revisited. Hydrobiologia 431:193-204.

Duarte CM, Conley DJ, Carstensen J, Sanchez-Camacho M. 2009. Return to Neverland: shifting baselines affect eutrophication restoration targets. Estuaries Coasts 32:29-36.

Eloranta P. 1986. Melosira distans var. tenella and Eunotia zasuminensis, two poorly known planktonic diatoms in Finnish lakes. Nordic J Bot 6:99-103.

Enache MD, Paterson AM, Cumming BF. 2011. Changes in diatom assemblages since pre-industrial times in 40 reference lakes from the Experimental Lakes Area (northwestern Ontario, Canada). J Paleolimnol 46:1-15.

Engstrom DR, Fritz SC, Almendinger J, Juggins S. 2000. Chemical and biological trends during lake evolution in recently deglaciated terrain. Nature 408:161-6.

Folke C, Carpenter S, Walker B, Scheffer M, Elmqvist T, Gunderson L, Holling C. 2004. Regime shifts, resilience, and biodiversity in ecosystem management. Annu Rev Ecol Evol Syst 35:557-81.

Fritz SC, Engstrom DR, Juggins S. 2004. Patterns of early lake evolution in boreal landscapes: a comparison of stratigraphic inferences with a modern chronosequence in Glacier Bay, Alaska. Holocene 14:828-40.

Gonzales LM, Grimm EC. 2009. Synchronization of late-glacial vegetation changes at Crystal Lake, Illinois, USA with the North Atlantic Event Stratigraphy. Quatern Res 72:234-45.

Hammarlund D, Björck S, Buchardt B, Thomsen C. 2005. Limnic responses to increased effective humidity during the $8200 \mathrm{cal}$. yr BP cooling event in southern Sweden. J Paleolimnol 34: 471-80.

Hede MU, Rasmussen P, Noe-Nygaard N, Clarke AL, Vinebrooke RD, Olsen J. 2010. Multiproxy evidence for terrestrial and aquatic ecosystem responses during the $8.2 \mathrm{ka}$ cold event as recorded at Højby Sø, Denmark. Quat Res 73:485-96.

Hill MO. 1973. Diversity and evenness: a unifying notation and its consequences. Ecology 54:427-32.

Houk V, Klee R. 2004. The stelligeroid taxa of the genus Cyclotella (Kützing) Brébisson (Bacillariophyceae) and their transfer into the new genus Discostella gen. nov. Diatom Res 19: 203-28.

Håkansson H. 2002. A compilation and evaluation of species in the general (sic) Stephanodiscus, Cyclostephanos and Cyclotella with a new genus in the family Stephanodiscaceae. Diatom Res 17:1-139.

Jackson D. 1993. Stopping rules in principal components analysis: a comparison of heuristical and statistical approaches. Ecology 74:2204-14.

Jeppesen E, Søndergaard M, Pedersen AR, Jürgens K, Strzelczak A, Lauridsen TL, Johansson LS. 2007. Salinity induced regime shift in shallow brackish lagoons. Ecosystems 10:47-57.

Jones VJ, Solovieva N, Self AE, McGowan S, Rosén P, Salonen JS, Seppä H, Valiranta M, Parrott E, Brooks SJ. 2011. The influence of Holocene tree-line advance and retreat on an arctic lake 
ecosystem: a multi-proxy study from Kharinei Lake, North Eastern European Russia. J Paleolimnol 46:123-37.

Jones VJ, Birks HJB. 2004. Lake-sediment records of recent environmental change on Svalbard: results of diatom analysis. J Paleolimnol 31:445-66.

Kobashi T, Severinghaus JP, Brook EJ, Barnola J-M, Grachev AM. 2007. Precise timing and characterization of abrupt climate change 8200 years ago from air trapped in polar ice. Quatern Sci Rev 26:1212-22.

Krammer K, Lange-Bertalot H. 1986. Bacillariophyceae. 1. Naviculaceae. In: Ettl H, Gärtner G, Gerloff J, Heynig H, Mollenhauer D, Eds. Süßwasserflora von Mitteleuropa, vol. 2. Stuttgart: Gustav Fischer Verlag. 876 pp.

Krammer K, Lange-Bertalot H. 1988. Bacillariophyceae. 2. Bacillariaceae, Epithemiaceae, Surirellaceae. In: Ettl H, Gärtner G, Gerloff J, Heynig H, Mollenhauer D, Eds. Süßwasserflora von Mitteleuropa, vol. 2. Stuttgart: Gustav Fischer Verlag. 596 pp.

Krammer K, Lange-Bertalot H. 1991a. Bacillariophyceae. 3. Centrales, Fragilariaceae, Eunotiaceae. In: Ettl H, Gärtner G, Gerloff J, Heynig H, Mollenhauer D, Eds. Süßwasserflora von Mitteleuropa, vol. 2. Stuttgart: Gustav Fischer Verlag. 576 pp.

Krammer K, Lange-Bertalot H. 1991b. Bacillariophyceae. 4. Achnanthaceae, Kritische Ergänzungen zu Navicula (Lineolatae) und Gomphonema. In: Ettl H, Gärtner G, Gerloff J, Heynig H, Mollenhauer D, Eds. Süßwasserflora von Mitteleuropa, vol. 2. Stuttgart: Gustav Fischer Verlag. 437 pp.

Lange-Bertalot H, Metzeltin D. 1996. Ecology-Diversity-Taxonomy. Indicators of oligotrophy-800 taxa representative of three ecologically distinct lake types. Iconographia Diatomologica 2:1-390.

Lees K, Pitois S, Scott C, Frid C, Mackinson S. 2006. Characterizing regime shifts in the marine environment. Fish Fish 7: 104-27.

Legendre P, Gallagher ED. 2001. Ecologically meaningful transformations for ordination of species data. Oecologia 129: 271-80.

LeGrande AN, Schmidt GA, Shindell DT, Field CV, Miller RL, Koch DM, Faluvegi G, Hoffmann G. 2006. Consistent simulations of multiple proxy responses to an abrupt climate change event. Proc Nat Acad Sci USA 103:837-42.

Lotter AF, Birks HJB, Eicher U, Hofmann W, Schwander J, Wick L. 2000. Younger Dryas and Allerød summer temperatures at Gerzensee (Switzerland) inferred from fossil pollen and cladoceran assemblages. Palaeogeogr Palaeoclimatol Palaeoecol 159:349-61.

Lotter AF, Bigler C. 2000. Do diatoms in the Swiss Alps reflect the length of ice-cover? Aquat Sci 62:125-41.

Lund JWG. 1955. Further observations on the seasonal cycle of Melosira italica (Ehr) Kütz subsp. subarctica O. Müll. J Ecol 43: 90-102.

Muscheler R, Beer J, Vonmoos M. 2004. Causes and timing of the $8200 \mathrm{yr}$ BP event inferred from the comparison of the GRIP ${ }^{10} \mathrm{Be}$ and the tree ring $\Delta{ }^{14} \mathrm{C}$ record. Quatern Sci Rev 23: 2101-11.

Ojala AEK. 2001. Varved lake sediments in southern and central Finland: long varve chronologies as a basis for Holocene palaeoenvironmental reconstructions. PhD thesis. Espoo: Geological Survey of Finland. 41 pp.

Ojala AEK, Heinsalu A, Kauppila T, Alenius T, Saarnisto M. 2008. Characterizing changes in the sedimentary environ- ment of a varved lake sediment record in southern central Finland around $8000 \mathrm{cal}$. yr BP. J Quat Sci 23:765-75.

Oksanen J, Kindt R, Legendre P, O'Hara B, Henry M, Stevens H. 2009. Vegan: community Ecology Package. R package version 1.15-4. http://CRAN.R-project.org/package=vegan.

Panizzo VN, Jones VJ, Birks HJB, Boyle JF, Brooks SJ, Leng MJ. 2008. A multiproxy palaeolimnological investigation of Holocene environmental change, between c. 10700 and 7200 years BP, at Holebudalen, southern Norway. Holocene 18:805-17.

R Development Core Team. 2011. R: a language and environment for statistical computing. Vienna: R Foundation for Statistical Computing.

Rasmussen SO, Andersen KK, Svensson AM, Steffensen JP, Vinther BM, Clausen HB, Siggaard-Andersen ML, Johnsen SJ, Larsen LB, Dahl-Jensen D, Bigler M, Röthlisberger R, Fischer H, Goto-Azuma K, Hansson ME, Ruth U. 2006. A new Greenland ice core chronology for the last glacial termination. J Geophys Res 111:D06102.

Rautio M, Sorvari S, Korhola A. 2000. Diatom and crustacean zooplankton communities, their seasonal variability and representation in the sediments of subarctic Lake Saanajarvi. J Limnol 59:81-96.

Reimer PJ, Baillie MGL, Bard E, Bayliss A, Beck JW, Bertrand CJH, Blackwell PG, Buck CE, Burr GS, Cutler KB, Damon PE, Edwards RL, Fairbanks RG, Friedrich M, Guilderson TP, Hogg AG, Hughen KA, Kromer B, McCormac G, Manning S, Bronk Ramsey C, Reimer RW, Remmele S, Southon JR, Stuiver M, Talamo S, Taylor FW, van der Plicht J, Weyhenmeyer CE. 2004. INTCAL04 terrestrial radiocarbon age calibration, 0-26 cal kyr BP. Radiocarbon 46:1029-58.

Renberg I, Segerström U. 1981. Application of varved lake sediments in paleoenvironmental studies. Wahlenbergia 7:125-33.

Renberg I. 1990. A procedure for preparing large sets of diatom slides from sediment cores. J Paleolimnol 4:87-90.

Rimet F, Druart J-C, Anneville O. 2009. Exploring the dynamics of plankton diatom communities in Lake Geneva using emergent self-organizing maps (1974-2007). Ecol Inform 4:99-1 10.

Rioual P, Guoqiang C, Jintai H, Mingram J. 2006. Holocene climatic and limnologic changes at Sihailongwan maar lake (Northeastern China) as indicated by diatom remains: preliminary results. Festschrift in honor of Dobrina TemniskovaTopalova.

Rohling EJ, Pälike H. 2005. Centennial-scale climate cooling with a sudden cold event around 8,200 years ago. Nature 434: 975-9.

Rosen P, Hall R, Korsman T, Renberg I. 2000. Diatom transferfunctions for quantifying past air temperature, $\mathrm{pH}$ and total organic carbon concentration from lakes in northern Sweden. J Paleolimnol 24:109-23.

Round FE, Bukhtiyarova L. 1996. Four new genera based on Achnanthes (Achnanthidium) together with a re-definition of Achnanthidium. Diatom Res 11:345-61.

Rühland K, Paterson AM, Smol JP. 2008. Hemispheric-scale patterns of climate-related shifts in planktonic diatoms from North American and European lakes. Glob Change Biol 14:2740-54.

Scheffer M, Jeppesen E. 2007. Regime shifts in shallow lakes. Ecosystems 10:1-3.

Scheffer M, van Nes EH. 2007. Shallow lakes theory revisited: various alternative regimes driven by climate, nutrients, depth and lake size. Hydrobiologia 584:455-66. 
Seppä H, Birks HJB, Giesecke T, Hammarlund D, Alenius T, Antonsson K, Bjune AE, Heikkila M, MacDonald GM, Ojala AEK, Telford RJ, Veski S. 2007. Spatial structure of the 8200 cal yr BP event in northern Europe. Clim Past 3:225-36.

Siver PA, Hamilton PB, Stachura-Suchoples K, Kociolek JP. 2005. Diatoms of North America. The freshwater Flora of Cape Cod. Iconogr Diatomol 14:1-463.

Smol JP, Douglas MSV. 2007. From controversy to consensus: making the case for recent climate using lake sediments. Front Ecol Environ 5:466-74.

Smol JP, Wolfe AP, Birks HJB, Douglas MSV, Jones VJ, Korhola A, Pienitz R, Rühland K, Sorvari S, Antoniades D, Brooks SJ, Fallu MA, Hughes M, Keatley BE, Laing TE, Michelutti N, Nazarova L, Nyman M, Paterson AM, Perren B, Quinlan R, Rautio M, Saulnier-Talbot E, Siitoneni S, Solovieva N, Weckström J. 2005. Climate-driven regime shifts in the biological communities of arctic lakes. Proc Nat Acad Sci USA 102:4397-402.

Smol JP. 1983. Paleophycology of a high arctic lake near Cape Herschel, Ellesmere-Island. Can J Bot 61:2195-204.

Snowball I, Muscheler R, Zillen L, Sandgren P, Stanton T, Ljung K. 2010. Radiocarbon wiggle matching of Swedish lake varves reveals asynchronous climate changes around the 8.2 kyr cold event. Boreas 39:720-33.

Spencer M, Birchenough SNR, Mieszkowska N, Robinson LA, Simpson SD, Burrows MT, Capasso E, Cleall-Harding P, Crummy J, Duck C, Eloire D, Frost M, Hall AJ, Hawkins SJ, Johns DG, Sims DW, Smyth TJ, Frid CLJ. 2011. Temporal change in UK marine communities: trends or regime shifts? Mar Ecol 32:10-24.

Stanton T, Snowball I, Zillén L, Wastegård S. 2010. Validating a Swedish varve chronology using radiocarbon, palaeomagnetic secular variation, lead pollution history and statistical correlation. Quat Geochronol 5:611-24.

Steffensen J-P, Andersen KK, Bigler M, Clausen HB, Dahl-Jensen D, Fischer H, Goto-Azuma K, Hansson M, Johnsen SJ, Jouzel J, Masson-Delmotte V, Popp T, Rasmussen SO,
Röthlisberger R, Ruth U, Stauffer B, Siggaard-Andersen ML, Sveinbjörnsdóttir AE, Svensson A, White JWC. 2008. Highresolution Greenland Ice Core data show abrupt climate change happens in few years. Science 321:680-4.

Stockmarr J. 1971. Tablets with spores used in absolute pollen analysis. Pollen Spores 13:615-21.

Tinner W, Lotter AF. 2001. Central European vegetation response to abrupt climate change at 8.2 ka. Geology 29:551-4.

Turkia J, Sandman O, Huttunen P. 1998. Palaeolimnological evidence of forestry practices disturbing small lakes in Finland. Boreal Environ Res 3:45-61.

Zillén L, Snowball I, Sandgren P, Stanton T. 2003. Occurrence of varved lake sediment sequences in Värmland, west central Sweden: lake characteristics, varve chronology and AMS radiocarbon dating. Boreas 32:612-26.

Zillen L, Snowball I. 2009. Complexity of the 8 ka climate event in Sweden recorded by varved lake sediments. Boreas 38 : 493-503.

Zimmer KD, Hanson MA, Herwig BR, Konsti ML. 2009. Thresholds and stability of alternative regimes in shallow prairie-parkland lakes of central North America. Ecosystems 12:843-52.

Veski S, Seppä H, Ojala AEK. 2004. Cold event at 8200 yr BP recorded in annually laminated lake sediments in Eastern Europe. Geology 32:681-4.

Wiersma AP, Renssen H. 2006. Model-data comparison for the 8.2 ka BP event: confirmation of a forcing mechanism by catastrophic drainage of Laurentide Lakes. Quatern Sci Rev 25:63-88.

Williams JW, Blois JL, Shuman BN. 2011. Extrinsic and intrinsic forcing of abrupt ecological change: case studies from the late Quaternary. J Ecol 99:664-77.

Yu Z. 2007. Rapid response of forested vegetation to multiple climatic oscillations during the last deglaciation in the northeastern United States. Quatern Res 67:297-303. 